\title{
Not Known if MGMT Promoter Methylation Testing Was Performed
}

National Cancer Institute

\section{Source}

National Cancer Institute. Not Known if MGMT Promoter Methylation Testing Was

Performed. NCI Thesaurus. Code C160460.

An indication that it is not known whether MGMT promoter methylation analysis was

performed during the study. 